\title{
Information and data quality in business networking: a key concept for enterprises in its early stages of development
}

\author{
Boris Otto $\cdot$ Yang W. Lee $\cdot$ Ismael Caballero
}

Received: 11 April 2011 / Accepted: 11 May 2011 /Published online: 26 May 2011

(C) Institute of Information Management, University of St. Gallen 2011

\begin{abstract}
Information and data of high quality are critical for successful business performance in general and Business Networking in particular. As the trend toward sharing information between business partners and value networks is still increasing, the position paper aims at providing a comprehensive perspective on the state of research with regard to information and data quality in Business Networking. The paper shows that much has been achieved, but that fundamental aspects still remain unaddressed. Based on the results of a literature review, the paper identifies consequential areas of research and makes six propositions for future research. In doing so, the position paper aims at offering novel perspectives and at introducing new areas of research in a field of particularly high relevance in the networked business and electronic markets domain.
\end{abstract}

Responsible editor: Hubert Österle

B. Otto $(\bowtie)$

Institute of Information Management, University of St. Gallen,

Müller-Friedberg-Strasse 8,

9000 St. Gallen, Switzerland

e-mail: boris.otto@unisg.ch

Y. W. Lee

Information, Operations and Analysis Group,

Northeastern University,

214 Hayden Hall, 360 Huntington Avenue,

Boston, MA 02115, USA

e-mail: y.lee@neu.edu

e-mail: ylee@mit.edu

I. Caballero

Department of Information Technologies and Systems,

University of Castilla-La Mancha,

Paseo de la Universidad 4,

13071 Ciudad Real, Spain

e-mail: Ismael.Caballero@uclm.es
Keywords Information quality · Data quality · Business networking $\cdot$ Literature review $\cdot$ Research directions

JEL classification L220-Firm Organization and Market Structure $\cdot$ M100-Business Administration: General . M150-IT Management

\section{Introduction}

Research in the area of information and data quality has advanced significantly over the past 20 years. There are several early examples of research vehicles and practice forums which played a key role in making the research and practice known to broader communities of practice. One such example is KPMG's Impact Club, which developed the key strategic principles to treat information as an asset (Horne 1995). The Massachusetts Institute of Technology (MIT) also introduced information and data quality research programs, such as the MIT Information Quality Program (MIT IQ) and Total Data Quality Management (TDQM), which contributed to the advancement of the field (Wang and Strong 1996; Wang et al. 1995, 1998). Much research effort today goes beyond the focus on the database systems alone, and challenges the conventional notion of ad-hoc cleaning or correction measures. These efforts have also established the area with a more comprehensive treatment of data and information quality in the context of organizational environment.

This evolution of information and data quality research was always closely related to the integration of information and data in enterprises. Integration efforts started decades ago with the integration of individual activities and sub-functions within an enterprise (see Phase 1 in Fig. 1). The organizational scope was subsequently extended to entire enterprise functions such 
Phase 1:

Programs

Computerized

functions

(e.g. billing)

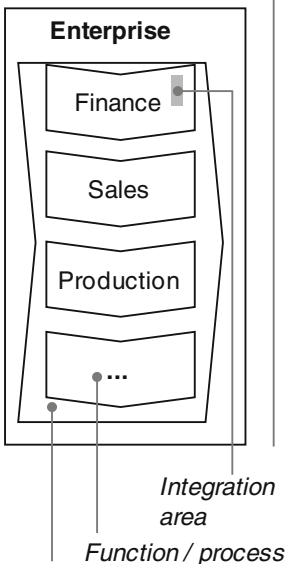

Business unit /

Enterprise
Phase 2:

Program systems

Computerized

functional areas (e.g

financial accounting)

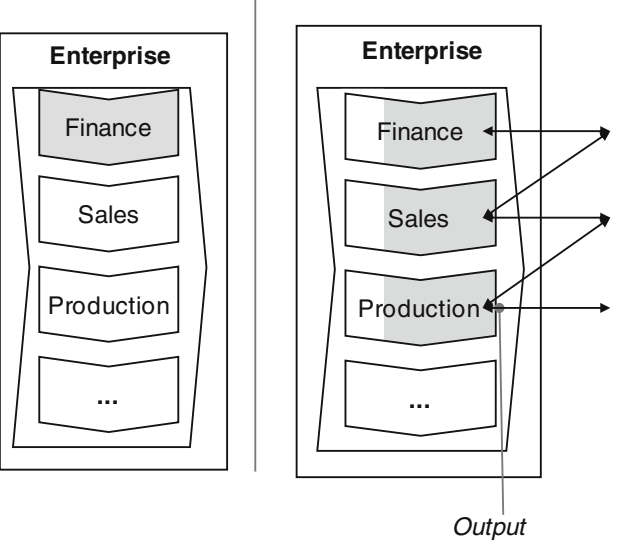

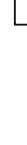

Integrated processes

(e.g. order processing,

"order to cash")

Phase 4:

1:1 Collaborative

processes

Cross-enterprise

(e.g. order management)

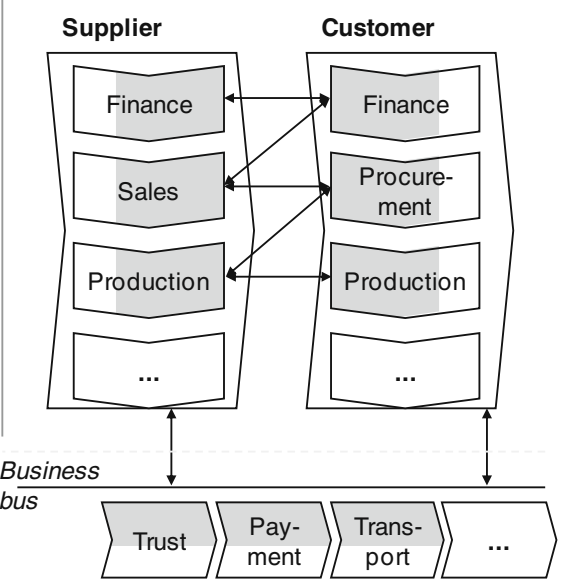

Phase 5:

m:n collaborative processes

(e.g. funds transfer via SWIFT)

Fig. 1 Development of business networking (Alt et al. 2001)

as accounting and sales in the 1970s and 1980s (Phase 2). The functional focus was replaced by emphasis on business processes and the implementation of Enterprise Systems in the 1990s (Davenport 1998; Davenport and Short 1990; Österle 1996) in Phase 3 of the development of Business Networking. With the emergence of the internet and the related increase in standardization as well as the simultaneous reduction in costs for electronic data interchange, integration went beyond the boundaries of the individual enterprise. The main focus at the time was on 1:1 processes between two business partners. With this as a foundation, Phase 5 in the development of Business Networking involves the collaboration of multiple business partners supported by information systems.

The importance of information and data quality for Business Networking was already emphasized back in 1998 when Wang et al. (1998) pointed out that "in an increasingly networked world, information of varying quality is being aggregated for business use", and that enterprises should "view, manage, and deliver information as a product". And with the demand for collaboration and information sharing in business networks still increasing today (Global Commerce Initiative et al. 2008), the position paper at hand addresses a twofold question: Where do we stand today in the research area of information and data quality in Business Networking and what are the fields of research to be addressed as a consequence?

The paper uses an extensive literature analysis to find answers to these questions. The results are analyzed from both a topical and an epistemological perspective. While the former asks which questions of information and data quality in Business Networking are addressed in the contribution, the latter asks what type of knowledge it produces. Based on the current status of research, the paper then develops some recommendations regarding directions that research should take in the future. The paper thus lays the foundation for future work in an area of research which is equally relevant to both the scientific and the practitioners' community.

\section{Theoretical background}

Information and data quality

Information is defined as "data processed" (Van den Hoven 1999). This notion corresponds with the understanding of information being a product manufactured from data as a raw material (Wang et al. 1998; Wang 1998). The analogy to the world of physical goods is true also for the understanding of information and data quality. Quality is subjective and, consequently, whether the quality of information or data is high or low always depends on the user's context. Besides being context-dependent, the quality of information and data is also a multidimensional concept, i.e. there is no single characteristic describing quality as an integral whole. There is rather an array of dimensions which are used to describe information and data quality. 
Typical information and data quality dimensions are accuracy, consistency, timeliness, and completeness.

Advances in research on data and information quality were made possible by understanding the environment, goals, and the stakeholders of sources of data, the storage and maintenance of data, and the utilization of data. It began with the historical study of information by Shannon (1949) on the physical noise of information as a quality issue, and research has continued to evolve by situating data and information in its post-industrial work environment. The often exemplified and sometimes sensationalized disastrous failures and mistakes due to poor-quality data exacerbated the need for data quality research and practice. Unexpected catastrophic mistakes, such as losing a shuttle to Mars or the surgical removal of the wrong leg, called for attention on the downside of data and information from a punitive perspective. On the other hand, the strategic implications of using data and information for effective communication opened up the benefit of understanding and managing data and information. Examples range from pinning down the detailed preference of data consumers to solving privacy and clinical research needs for patient data. Researchers began to develop theories based on rich empirical findings. One example shows how contexts of data are explicated throughout the problem-solving activities of data quality practitioners while engaged in crossdisciplinary learning and faced with solving data quality problems (Lee 2004).

Many data quality practitioners made important contributions by highlighting the problem and applying their solution methodology in both private and public sector organizations (English 1999; Redman 1995; Loshin 2001). Diverse research methods were used to produce various theories aimed at the understanding and assessment of data quality, identifying root-causes, supporting the work on data problems, and understanding the maturity of data quality management (Shankaranarayanan and Cai 2006; Eppler and Helfert 2004; Caballero et al. 2008). Apart from that, frameworks were proposed to establish information and data quality as an organizational function. Examples are Corporate Data Quality Management (Otto 2011; Otto et al. 2007) and Complete Data Quality Management (Batini and Scannapieco 2006). In this context, Data Governance is a topic of increasing prominence both in the scientific and the practitioners' community. Data Governance aims at identifying and assigning roles and responsibilities related to the management of information and data quality in the organization (Khatri and Brown 2010; Weber et al. 2009).

Moreover, research was undertaken to explore data quality problems and solutions that might portray specific needs in various industries, such as healthcare, the financial industry, mortgage industry, pharmaceutical industry or the manufacturing industry. Recently, studies in the area of digital government have also identified new and enhanced participation discourse using digital channels and quality data (Yao and Murphy 2007; Fedorowicz et al. 2010).

In terms of the professional community, an increasing number of researchers and practitioners are establishing and sharing ideas and solutions. The Special Interest Group on Information Quality (sigIQ) within the Association for Information Systems (AIS) is an example from the academic research side, and there are many more communities that have been established. Furthermore, various researchers have published literature reviews on data and information quality (Batini et al. 2009; Madnick et al. 2009). The ACM Journal of Data and Information Quality and the International Journal of Information Quality have also emerged as examples of pioneering journal outlets for data and information quality. There are many special issues of leading journals, including the current business networking issue.

\section{Business networking}

Business Networking has its roots in the 1990s, when the term was initially used in the IS community. Business Networking is defined as the organization and management of IT-supported business relationships with internal and external business partners (Österle et al. 1999).

Business Networking is closely related to three other concepts, namely business model, networked business, and electronic market. A business model is the architecture for the product, service and information flows, including a description of the various business actors and their roles as well as their potential benefits and sources of revenue (Timmers 1999; Osterwalder and Pigneur 2010). The need for a term such as business model was justified by the changes which the rise of IT, in particular the internet, would mean for traditional businesses. The envisaged restructuring of value chains was seen as a driver for a more detailed understanding of the architecture and "mechanism" of businesses. The creation of business networks in particular would pave the way for networked business models (Applegate 2001). Consequently, a networked business is defined as "a 'mix-and-match' web of profit-and-loss responsible business units, or of independent companies, connected by IT that work together for a unifying purpose for a specific period of time" (Tapia 2006).

Electronic markets represent a form of Business Networking. Alt and Klein (2011) give a comprehensive overview of electronic market research. They point out two origins of electronic markets, namely the technological side with its roots in electronic data interchange (EDI) and the economic side which mainly analyzes the cost of economic activity between organizations. They also foresee a convergence of 
Business Networking concepts and electronic markets when proposing combinations of both network and governancedriven organizational forms for "all-in-one" marketplaces.

Research has taken a variety of perspectives on Business Networking. Examples are the transaction cost theoretical perspective (Williamson 1979), a coordination theoretical (Malone and Crowston 1994) and organizational theoretical perspective (Miles and Snow 1992). However, much attention has been paid to the business process perspective on Business Networking introduced by Fleisch and Österle (2000). Their approach considers Business Networking to be based on Business Engineering (Österle 1996; Österle and Winter 2003), which stipulates that Business Networking requires action on three layers, namely Strategy, Processes, and Systems. Business Engineering is the method-oriented and model-based design approach for companies in the information age (Österle 1996; Österle and Winter 2003). The tripartite structure of the Business Networking framework has been confirmed by further research (Riemer and Klein 2006).

The framework in Fig. 2 suggests that Business Networking requires three fundamental capabilities on a business network layer, namely "networkability", "service enablement", and "ecosystem management". Networkability is the internal and external ability to cooperate as well as the ability to rapidly and efficiently establish, conduct and develop IT-supported business relationships (Alt et al. 2000). Service enablement refers to the ability of a company to support the customer process as a whole, in contrast to providing products which are used by the customer in certain activities of his/her process. A business ecosystem includes customers, lead producers, competitors, and other stakeholders (Kagermann et al. 2010). Leadership companies which orchestrate the various stakeholders are key to a business ecosystem (Moore 1996).

The process network is characterized by the orchestration of six collaborative business processes (Dayal et al. 2001; Legner and Wende 2006), namely content and community management, product lifecycle management, commerce, supply chain management, maintenance and repair processes, and financial support processes.

On the Information Systems layer, the Business Networking Framework distinguishes between application systems and infrastructure. The former comprise three different types of application systems, namely electronic commerce systems, supply chain management systems, and data sharing systems (Alt and Fleisch 2000), while the latter consists of a business collaboration infrastructure (Österle et al. 1999) and IS standards. IS standards which are relevant for Business Networking are mainly those which aim at ensuring business interoperability (Legner and Lebreton 2007). Examples are RosettaNet, which was initially developed in the high tech and semiconductor industry, and HR-XML in the temporary staffing sector.

\section{Information and data quality in business networking}

As a basis for the further course of the investigation, an integrated conceptual framework for information and data quality in Business Networking is introduced (see Fig. 3).
Fig. 2 Business networking framework

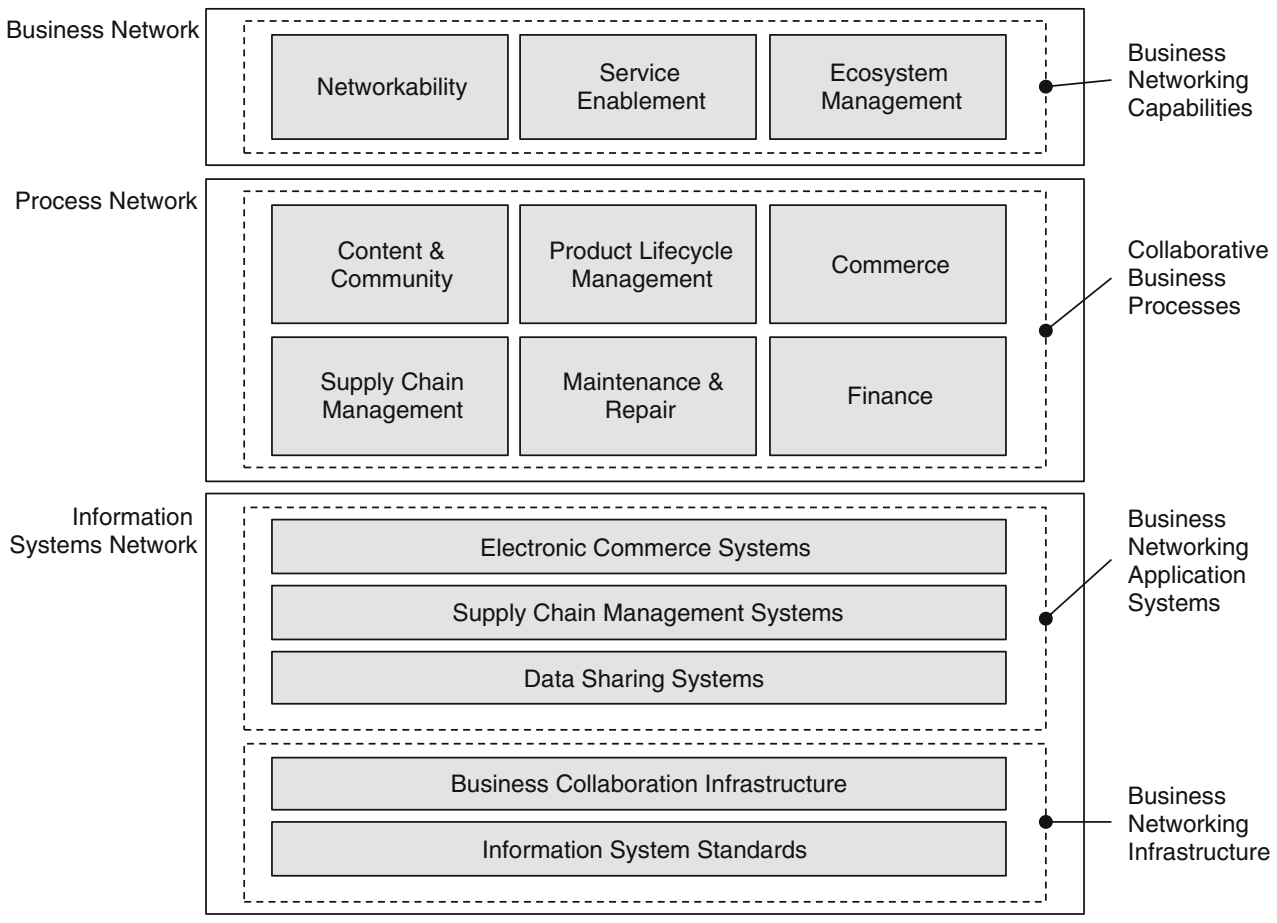


Fig. 3 Conceptual framework of information and data quality in business networking
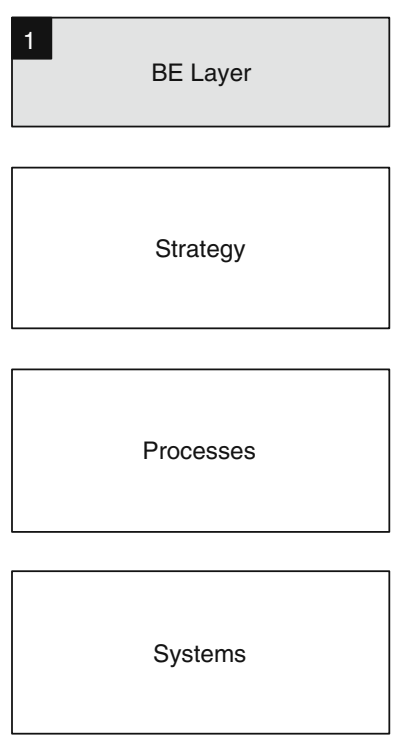
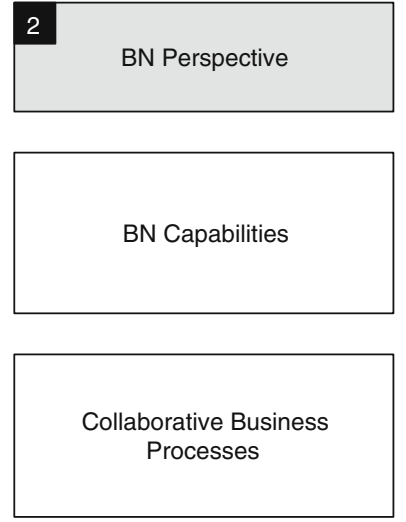

BN Application Systems

BN Infrastructure

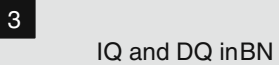

- IQ and DQ as Competitive Factor for BN Success

- IQ and DQ asEnabler for BN

Capabilities

- Metrics for IQ and DQ in BN

- IQ and DQ Responsibilities in $\mathrm{BN}$

- Information and Data Lifecycle Management in BN

- Information and Data

Architectures in BN

- Application and Infrastructure

Systems Supporting IQ and $D Q$ in $B N$

Legend: BE-Business Engineering; BN-Business Networking; IQ- Information Quality; DQ- Data Quality.

The conceptual framework assumes Business Engineering (see above) to be the shared conceptual model (denoted "1" in the viewgraph in Fig. 3) for both Business Networking and institutionalized forms of information and data quality management. The middle of the viewgraph (denoted "2") shows the different Business Networking layers as introduced in Fig. 2. Finally, fundamental concepts from the perception of information and data quality management as an organizational task (Otto 2011; Otto et al. 2007) were assigned to the Business Networking layers (denoted "3"). The transfer of the information and data quality concepts from the intra-organizational to an inter-organizational context was inferred since both Business Networking and institutionalized information and data quality management follow the principles of Business Engineering. As a result, the integrative perspective (denoted "3") includes seven concepts.

Information and data quality as a competitive factor in Business Networking relates to the question of the extent to which information and data quality is decisive for the success of Business Networking efforts and therefore has a value in its own right. In contrast, information and data quality as an enabling factor refers to high-quality information and data as being mandatory, but not in itself sufficient for success. The enabling function of information and data quality is frequently referred to as the "hygiene factor".

With regard to collaborative business processes, three concepts from the intra-organizational perspective of information and data quality can be transferred to Business Networking. First, metrics must be introduced in order to appropriately analyze, improve, and ensure information and data quality (Lee et al. 2002). Second, responsibilities must be identified and assigned with regard to information and data quality. In an intra-organizational context, this task is often described as "Data Governance" (Kathri and Brown 2010; Sarsfield 2009). Third, the lifecycle of information and data from creation to archiving or deletion has to be managed across the boundaries of business partners.

Finally, on the Business Networking Systems layer, information and data architectures must be defined. This concept includes conceptual models of shared information and data, and the architecture of application systems which store this data as well as the flows of information and data between the systems (Otto and Schmidt 2010). And moreover, the integrated perspective includes application and infrastructure

Table 1 Business networking search terms

\begin{tabular}{ll}
\hline Business network layers & Search terms \\
\hline Business network & - Business networking, business network \\
& - Networking \\
& - Service-enabled, service enablement \\
& - Service \\
& - Ecosystem, eco-system \\
& - Collaborative, collaboration \\
& - Content, community \\
& - Product lifecycle, product life-cycle \\
& - Commerce, eCommerce \\
Process network & Supply chain, SCM \\
& - Maintenance, repair \\
& - Finance \\
& - System integration \\
& - Data sharing, shared data \\
- ISteroperability & - Standard, IS standard
\end{tabular}


systems which are used to analyze, improve, and ensure information and data quality in Business Networking.

\section{Literature review}

The paper uses a literature review to determine the state of research with regard to information and data quality management in Business Networking.

In Step 1, the Business Networking concepts introduced above were translated into search terms (see Table 1). The Business Network layer was operationalized by using five terms. The business capability "Networkability" as introduced by Alt et al. (2000) was replaced by the more general term "Networking" in order to generate more search results. For the same reason, the concept "Service" was introduced as a search term. The layer "Process Network" includes all collaborative processes presented in Fig. 2 as search terms as well as the generic concepts of "collaboration" and "collaborative". The layer "Information Systems Network" does not include the concepts "eCommerce" and "Supply Chain" because both terms are included in the Process Network category. The "Business Collaboration Infrastructure" was operationalized through the more general terms "System Integration" and "Interoperability".

Step 2 was aimed at identifying electronic libraries in which to search. The libraries were supposed to cover "mainstream" IS sources, but also reflect the information and data quality community. Therefore, four libraries were selected, namely EBSCO Online, ${ }^{1}$ Emerald, ${ }^{2}$ the AIS Electronic Library, ${ }^{3}$ and the Proceedings of the International Conference on Information Quality. ${ }^{4}$

Step 3 included the search using literature within the four libraries. In the course of the search, the concepts "Information Quality" and "Data Quality" were joined pairwise with the search terms listed in Table 1. A search string example is "Information Quality" AND ("Business Network" OR "Business Networking"). A similar approach was used by Kitchenham et al. (2006) in their analysis of cost estimation studies. In total, 32 searches were performed in all four libraries. The total number of searches is obtained by multiplying the 16 Business Networking search terms (see Table 1) by the two search terms "Information Quality" and "Data Quality".

Table 2 shows the details of the search processes in the four libraries. Step 3 led to 179 papers which were then analyzed further. Based on this quantitative analysis, Step 4 concentrated on those papers which covered more than one Business Networking concept and hence address Business

\footnotetext{
${ }^{1}$ See http://ejournals.ebsco.com/home.asp.

${ }^{2}$ See http://www.emeraldinsight.com/.

${ }^{3}$ See http://aisel.aisnet.org/.

${ }^{4}$ Available under: http://mitiq.mit.edu/iciq/iqproceedings.aspx.
}

Networking in a more comprehensive way. Step 4 led to 35 papers which were analyzed in greater detail.

\section{Research on information and data quality in business networking}

\section{Descriptive analysis}

Application of the methodology described above resulted in an extensive amount of literature related to the conceptualization of information and data quality in Business Networking (see Table 3).

The Business Networking concept most frequently discussed in combination with Information Quality or Data Quality is "Service". However, the 80 results listed cover the entire spectrum of interpretation for the term "service", ranging from an understanding as a technical web service to an offering to the customer. Other Business Networking concepts which are discussed intensively in combination with Information and Data Quality are "Commerce", "Content" or "Community" as well as "Supply Chain", and "Standard". Interestingly, though, fundamental constituents of Business Networking such as "Networking", "Ecosystem", and "Interoperability" are underrepresented. In the case of ecosystem, the silence of the research community might be attributed to the adoption of the term. However, in the case of interoperability, this argument does not hold true. Only one paper addresses the topic of interoperability in combination with Information or Data Quality, namely the contribution by Oliveira et al. (2006) who propose an ontology-based approach for data cleansing. This stands in contrast to the importance of the role that high-quality information and data plays in achieving interoperability. Apart from that, only one paper addresses the concept of "Business Network" or "Business Networking". The paper by Helfert and Radon (2000) deals with information quality measurement in data warehousing and uses the concept of "Business Networking" to motivate the paper. However, it falls short in applying the information quality measurement approach to a business networking environment, for example. Specific concepts of Business Networking such as Product Lifecycle Management and Data Sharing are not represented at all. The filtering of papers which address at least two different Business Networking concepts leads to a list of 35 contributions. The appendix (Table 5) lists these papers and shows their coverage of Business Networking concepts.

Qualitative analysis

A qualitative analysis of the 35 papers takes the investigation of the type of contribution a stage further. The analysis uses 
Table 2 Literature search

\begin{tabular}{|c|c|c|c|c|}
\hline Search details & EBSCO online & Emerald & AIS electronic library & ICIQ proceedings $^{\mathrm{a}}$ \\
\hline Search functionality & "Find Articles by Text" & “Advanced search" & $\begin{array}{l}\text { "Advanced search" } \\
\text { with "match all" }\end{array}$ & $\begin{array}{l}\text { Search functionality of } \\
\text { Adobe Acrobat Pro }\end{array}$ \\
\hline Search date & 21-MAR-2011 & 25-MAR-2011 & 28-MAR-2011 & 28-MAR-2011 \\
\hline Searched fields & Title, abstract, and full text & All except full text & Abstracts & Abstracts, title \\
\hline Restrictions/Limitations & $\begin{array}{l}\text { Library, social, and } \\
\text { technology science only }\end{array}$ & Journals only & Peer-reviewed only & Years 2000 to $2010^{\mathrm{b}}$ \\
\hline Remarks & $\mathrm{n} / \mathrm{a}$ & $\mathrm{n} / \mathrm{a}$ & $\begin{array}{l}\text { Doctorial consortia of } \\
\text { conferences not included }\end{array}$ & $\begin{array}{l}\text { Practice papers excluded (mainly } \\
\text { MS PowerPoint format) }\end{array}$ \\
\hline
\end{tabular}

a Search terms included the Business Networking concepts only, not the terms "Information Quality" and "Data Quality" because it was assumed that, due to the nature and scope of the conference, all submissions relate to the topic

${ }^{\mathrm{b}}$ Earlier proceedings were not included because they are not available in a searchable format

two dimensions. The first dimension is taken from the integrated conceptual framework for information and data quality in Business Networking (denoted "3" in Fig. 3). This dimension represents a topical perspective on the current state of research. The second dimension takes an epistemological view and asks for the type of theory which was proposed in the contribution (see Table 4). In an adaption from Gregor (2006) and Winter (2008), this dimension distinguishes three values:

- Concepts represent analytical theories and describe "what is" (Type I).

- Cause-effect relations represent explaining and predicting theory (Type II).
- Means-end relations represent theory for designing and also include instantiations (Type III).

Business Networking capabilities are relatively unexplored. No contribution could be found addressing information and data quality in combination with networkability and management of the ecosystem. Many papers address information and data quality related to services, but show a different understanding of the service concept (often as a principle to provide software functionality). Among the few papers which fall into the Business Networking capability category are the contributions by Guimaraes et al. (2006) who apply the DeLone \& McLean model for IS success (DeLone and McLean 1992), the report of Loonam and O'Loghlin (2008) on service

Table 3 Search results overview

\begin{tabular}{|c|c|c|c|c|c|c|}
\hline Category & Concepts & $\begin{array}{l}\text { EBSCO } \\
\text { online }\end{array}$ & Emerald & $\begin{array}{l}\text { AIS electronic } \\
\text { library }\end{array}$ & ICIQ proceedings & Total \\
\hline \multirow[t]{5}{*}{ Business network } & Business networking OR business network & 0 & 0 & 0 & 1 & 1 \\
\hline & Networking & 0 & 2 & 0 & 3 & 5 \\
\hline & Service-enabled OR service enablement & 0 & 0 & 0 & 0 & 0 \\
\hline & Service & 6 & 37 & 17 & 20 & 80 \\
\hline & Ecosystem OR eco-system & 1 & 0 & 0 & 0 & 1 \\
\hline \multirow[t]{7}{*}{ Process network } & Collaborative OR collaboration & 2 & 3 & 2 & 5 & 12 \\
\hline & Content OR community & 4 & 5 & 16 & 13 & 38 \\
\hline & Product lifecycle OR product life-cycle & 0 & 0 & 0 & 0 & 0 \\
\hline & Commerce OR eCommerce & 0 & 15 & 2 & 4 & 21 \\
\hline & Supply chain OR SCM & 1 & 11 & 2 & 4 & 18 \\
\hline & Maintenance OR repair & 0 & 1 & 0 & 6 & 7 \\
\hline & Finance & 0 & 0 & 0 & 0 & 0 \\
\hline \multirow[t]{4}{*}{ Information systems network } & System integration & 0 & 0 & 0 & 0 & 0 \\
\hline & Data sharing OR shared data & 0 & 0 & 0 & 0 & 0 \\
\hline & Interoperability & 0 & 0 & 0 & 1 & 1 \\
\hline & Standard OR IS standard & 0 & 5 & 7 & 10 & 22 \\
\hline \multicolumn{2}{|c|}{ Total no. of results (duplicate records excluded) } & 13 & 62 & 44 & 60 & 179 \\
\hline
\end{tabular}


Table 4 Qualitative analysis of the current state of research

\begin{tabular}{|c|c|c|c|c|}
\hline $\mathrm{BN}$ concepts & IQ and DQ in BN Concepts & Type I: Concepts & $\begin{array}{l}\text { Type II: Cause-effect } \\
\text { relations }\end{array}$ & $\begin{array}{l}\text { Type III: Means-end } \\
\text { relations }\end{array}$ \\
\hline \multirow[t]{2}{*}{ BN capabilities } & $\begin{array}{l}\text { - IQ and DQ as competitive } \\
\text { factor for BN success }\end{array}$ & 0 & - & O \\
\hline & $\begin{array}{l}\text { - IQ and DQ as enabler for BN } \\
\text { capabilities }\end{array}$ & $\begin{array}{l}\text { Example: (Guimaraes } \\
\text { et al. 2006) }\end{array}$ & $\begin{array}{l}\text { Examples: (Lin 2010), } \\
\text { (Loonam and O’Loghlin } \\
\text { 2008), (Melkas 2004) }\end{array}$ & Example: not applicable \\
\hline \multirow{3}{*}{$\begin{array}{l}\text { Collaborative } \\
\text { business processes }\end{array}$} & - Metrics for IQ and DQ in BN & O & 0 & ○ \\
\hline & $\begin{array}{l}\text { - IQ and DQ responsibilities in } \\
\text { BN }\end{array}$ & $\begin{array}{l}\text { Examples: (Cullen and } \\
\text { Taylor 2009), (Park } \\
\text { and Kim 2003) }\end{array}$ & $\begin{array}{l}\text { Examples: (Forslund and } \\
\text { Jonsson 2007), (Nath and } \\
\text { Standing 2010), (Lin 2010), } \\
\text { (Maditinos and Theodoridis } \\
\text { 2010) }\end{array}$ & $\begin{array}{l}\text { Examples: (Nakatani et } \\
\text { al. 2006), (Pokorny } \\
\text { 2006) }\end{array}$ \\
\hline & $\begin{array}{l}\text { - Information and data } \\
\text { lifecycle management in } \mathrm{BN}\end{array}$ & & & \\
\hline \multirow{2}{*}{$\begin{array}{l}\text { BN application } \\
\text { systems \& } \\
\text { infrastructure }\end{array}$} & $\begin{array}{l}\text { - Information and data } \\
\text { architectures in BN }\end{array}$ & 0 & 0 & 0 \\
\hline & $\begin{array}{l}\text { - Application and Infrastructure } \\
\text { Systems Supporting IQ and } \\
\text { DQ in BN }\end{array}$ & $\begin{array}{l}\text { Example: (Sarkis and } \\
\text { Sundarraj 2000) }\end{array}$ & $\begin{array}{l}\text { Example: (Nakatani et al. } \\
\text { 2006) }\end{array}$ & $\begin{array}{l}\text { Examples: (Wigand et } \\
\text { al. 2009), (Zhu and } \mathrm{Fu} \\
\text { 2009a) }\end{array}$ \\
\hline
\end{tabular}

$B N$ business networking; $I Q$ information quality; $D Q$ data quality

$\bigcirc$ Concept not covered at all; $\bigcirc$ Concepts addressed to a small extent; $\bigcirc$ Concept partially addressed (e.g. three out of six collaborative processes); Concept addressed to a large extent; $\bullet$ Concept fully addressed

quality in online banking, and the paper by Lin (2010) from the tourism sector. In addition, Melkas (2004) analyzes information quality in virtual service networks. No paper, though, could be found which makes recommendations on designing methods and models for ensuring information and data quality on a strategic Business Networking layer.

Information and data quality aspects in individual collaborative business processes are relatively well addressed, in particular supply chain management and electronic commerce. These include contributions dealing with supply chain management, such as Auramo et al. (2005) analyzing the benefits of IT and the role of information quality therein for supply chain management, Claassen et al. (2008) studying vendor-managed inventory scenarios, and Nakatani et al. (2006) in their research on data synchronization. Examples of research on information and data quality in electronic commerce are the papers by Cullen and Taylor (2009), who identify information and data quality as a success factor for electronic commerce in pharmaceutical supply chains in the UK, and Park and Kim (2003), who obtain similar findings with their research into purchase behavior in online shops. The majority of papers in this category study cause-effect relations (Type II). They find information and data quality positively related to supply chain performance (Forslund and Jonsson 2007; Nath and Standing 2010), the perceived usefulness of electronic commerce websites (Rotchanakitumnuai and Speece 2009; Lin 2010), and customer satisfaction (Liu et al. 2008; Maditinos and Theodoridis 2010; Park and Kim 2003). While these findings are undoubtedly valuable when it comes to understanding the effects of information and data quality in Business Networking, the scientific community falls short in investigating what companies can actually do in order to manage the quality of information and data in collaborative business processes. Only few contributions make recommendations for addressing the issue. Examples are Nakatani et al. (2006) providing alternative approaches for global data synchronization, and Pokorny (2006) proposing a methodology for data enhancement in the supply chain of the U.S. Defense Logistics Agency.

Six of the contributions listed in Appendix deal with standardization issues and hence address the system layer of Business Networking. However, only four focus on information and data quality in the context of standardization enabling Business Networking. Nakatani et al. (2006) discuss whether data synchronization approaches help to overcome existing issues with data quality in Business Networking scenarios. Sarkis and Sundarraj (2000) propose a conceptual framework for the evaluation of electronic commerce websites. And both Wigand et al. (2009) and $\mathrm{Zhu}$ and $\mathrm{Fu}$ (2009a) examine the quality of instantiations of standards, namely the standards maintained by the Mortgage Industry Standards Maintenance Organization (MISMO) and the eXtensible Business Reporting Language (XBRL).

Interpretation of results

The results of the qualitative analysis allow for a number of interpretations. First, a significant amount of research has been carried out addressing information and data quality 
aspects in Business Networking. However, a closer look at the contributions shows a very fragmented picture. Many papers address information and data quality aspects in combination with individual concepts of Business Networking, often collaborative business processes. A comprehensive approach to the issue as a whole is currently missing. Where the evolution of integration from a functional toward an inter-organizational scope (see Fig. 1) is concerned, one could come to the conclusion that research into information and data quality has yet to take the next steps to ensure that Business Networking questions are also addressed in their entirety.

Second, while the Process Network layer is relatively well explored, information and data quality in respect of the Business Network and the Systems Network layers is still in its infancy.

Third, current research has so far displayed a tendency toward analytic theories (Type I) and explaining and predicting theories (Type II). Design artifacts for managing information and data quality in Business Networking are very rare. This might be explained, however, by the research paths that Gregor (2006) identifies when describing how different types of theories in IS are based on each other. Following this argumentation, the phenomenon that a field of research first produces concepts and analyzes cause-effect relations before proposing means-end relations can be seen as typical.

Summarizing, the analysis of the results of the literature review shows that information and data quality in Business Networking as an area of research is in its early stages of development. Much research has been undertaken so far, but the current body of knowledge does not match the increasing relevance of the topic for enterprises.

\section{Propositions for future research}

Motivated by the gap in literature regarding information and data quality in Business Networking on the one hand and the importance of the topic for enterprises on the other hand, this position paper makes propositions for future areas of research. The six propositions are also inspired by existing research results dealing with information and data quality within individual organizations which could be transferred to an inter-organizational environment. In congruence with the ambition of position papers, the propositions aim at stimulating the discussion in the community, and do not lay claim to completeness. They rather intend to offer novel perspectives and introduce new areas of discourse.

Research proposition 1 With the proliferation of Business Networking, the notion of "information as a product" will be further developed toward "information is the product".
Wang (1998) applied quality management principles for physical goods to the management of information and data, and proposed managing information as a product. Today's Business Networking ecosystems increasingly include business partners with an "information is the product" business model. Examples are providers of business partner data such as Avox, ${ }^{5}$ Bureau van Dijk, ${ }^{6}$ and D\&B, ${ }^{7}$ and intermediaries such as $\mathrm{GS}^{8}{ }^{8}$ in the field of product data. The information quality of their information products will affect the performance of Business Networking in the same way as the quality of physical goods does today. Future research should focus on understanding business models of "information product suppliers" and analyzing the role of information and data quality therein. Also, the concept of "corporate household data" should be applied to Business Network settings. Madnick et al. (2001) define that "any group of persons united or regarded as united with the corporation, such as suppliers and customers whose relationships with the corporation must be captured, managed, and applied for the purpose of activities such as marketing promotion, financial risk analysis, and supply chain management in their entirety forms a corporate household".

Research proposition 2 The "consumerization" of business will foster the transfer of information and data quality research to Business Networking.

The development of social networking and the "consumerization" of businesses will lead to an increasing involvement of consumers in Business Networking activities (Dholakia and Firat 2006; Sarner et al. 2008). Swiss retailer Migros, for example, took up the results of a voting project among consumers on its online community platform "Migipedia" and, as a consequence, introduced new packaging for one of its ice tea products (MGB 2010). Research on information and data quality management should advance the (significant) body of knowledge regarding the role of information and data quality in electronic commerce and online shopping settings toward consumer interaction in Business Networking. Moreover, research results investigating information and data quality in social networking should also be leveraged. An example is the methodology proposed by $\mathrm{Zhu}$ and $\mathrm{Wu}(2009 \mathrm{~b})$ aimed at assessing collaborative social tagging quality.

Research proposition 3 The role of information and data quality in Business Networking will intensify the discussion about accounting for information and data as assets.

\footnotetext{
${ }_{5}^{5}$ See http://www.avox.info/.

${ }^{6}$ See http://www.bvdinfo.com.

${ }^{7}$ See http://www.dnb.com.

${ }^{8}$ See http://www.gs1.org/.
} 
The current debate on the accounting recognition of information and data as assets is determined by the question of whether information and data should be included in a corporate balance sheet. Some researchers argue that their absence from balance sheets was largely due to the accounting profession's failure in coming up with generally accepted guidelines for identifying and recognizing as well as measuring and valuing intangible assets of all kinds (Wilson and Stenson 2008). Atkinson and McGaughey (2006) also stipulate that measuring the value of data is a "doable" task that begs attention now. Research should be intensified in this field as Business Networking is increasingly relying on information and data services (see Proposition 1). This direction is also envisioned by the European Commission. The position paper on orientations for the 8th Framework Program (FP8) entitled "A European Innovation Partnership for Catalysing the Competitiveness of European Enterprises" addresses the value of intangibles in the context of business models associated with new technologies and trends such as Web 2.0 and Enterprise 2.0 (FInES Cluster 2011).

Research proposition 4 Corporate Data Governance will evolve into Network Data Governance.

Data Governance is receiving increasing attention both in the researchers' and in the practitioners' community. Data Governance aims at identifying and assigning decision rights and responsibilities related to information and data quality management in organizations (Khatri and Brown 2010; Weber et al. 2009; Sarsfield 2009). At present, Data Governance takes a "corporate", i.e. internal view, but, with the further emergence of the Business Networking demand for "network data governance" approaches, is likely to increase. Research should analyze limitations and boundaries of existing Data Governance models, and propose methods and guidelines for Data Governance in networked business scenarios.

Research proposition 5 There will be a need to transfer approaches to managing information and data quality in business processes toward their use in business networks.

The process of manufacturing information products has long been a field of research in the information and data quality community. Redman (2001), for example, refers to information chains when taking an integrative view on the flow of information and data in business processes. Shankaranarayan et al. (2000) introduces IP-MAP as a method to analyze, model and design information production processes. And Berti-Équille (2007) proposes an approach to analyze data flows in heterogeneous application system landscapes to trace data pollution. These contributions, however, are today mainly internal-facing. In future, they should be leveraged to provide models, methods, and instruments to manage information and data lifecycles in Business Networking. Otto and Ofner (2010), for example, took this path when developing a process reference model for information supply chain management.

Research proposition 6 Architectural styles to ensure corporate data quality will increasingly also include decentralized approaches such as linked data.

Today, central data architectures are the prevailing approach to ensure the quality of corporate data, i.e. data on key business objects in a company (e.g. suppliers, materials, customers) (Otto and Schmidt 2010; Dreibelbis et al. 2008). Central data architectures are based on the principle of a "single source of the truth" which is often held in a central database. This architectural style will be hardly feasible and manageable in future Business Networking environments. As mentioned above, Nakatani et al. (2006) discuss multiple challenges in today's data synchronization approaches. Research should further investigate the potential and the limitations of decentralized approaches to data architecture. Allemang (2010), for example, discusses linked data architectures as a promising approach.

The six research propositions aim at overcoming the gaps in literature identified above. Responding to the need of a comprehensive view on information and data quality in Business Networking, they address all three layers of the conceptual framework in Fig. 3. While propositions 1 and 2 are located on the strategic layer, for example, the proposition of Network Data Governance relates to organizational aspects. And decentralized approaches to data architecture address the "Systems" layer.

Apart from that, the propositions stimulate research mainly regarding means-end relations (what is a shortcoming today). For instance, proposition 5 suggests the design of methods and models for information and data quality in Business Networking.

\section{Conclusions}

This paper reports on the state of the research with regard to information and data quality in Business Networking and, based on that, proposes a set of future research directions. Seen individually, both information and data quality and Business Networking are mature fields of research. The literature review led to numerous contributions which address particular information and data quality aspects in Business Networking. Relatively well explored, for example, is the relevance of information quality for the success of electronic commerce and online shopping websites. However, the analysis also identified funda- 


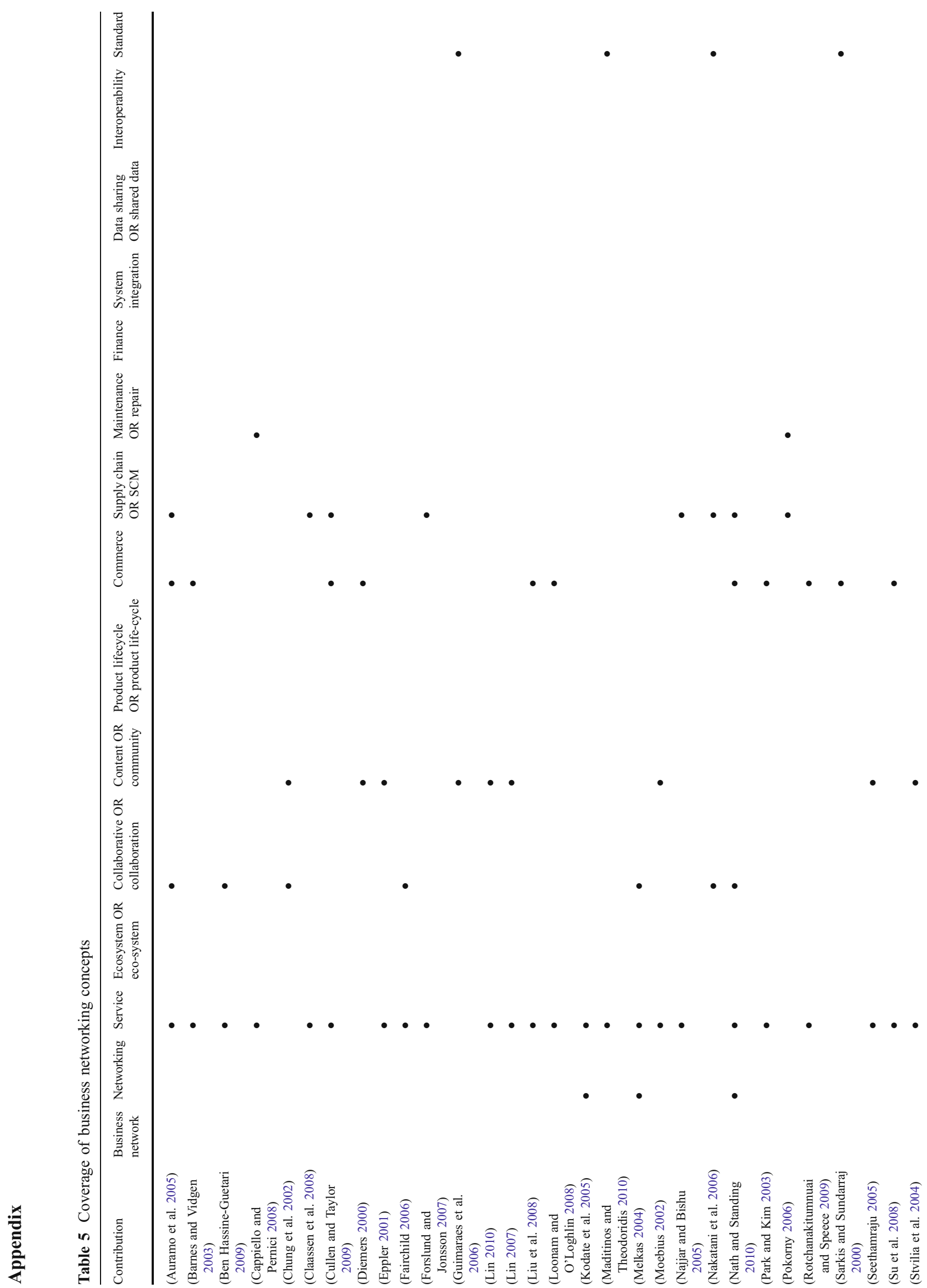




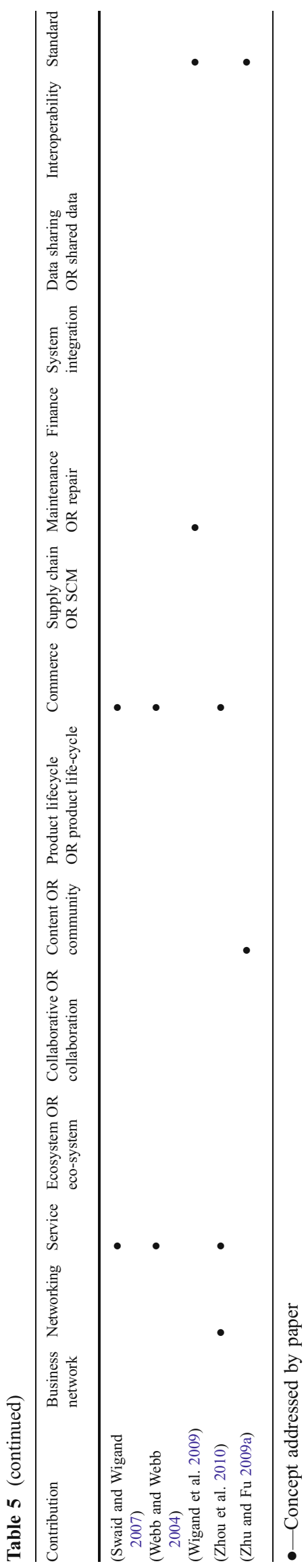

mental gaps in the literature. Especially, comprehensive frameworks for information and data quality management in Business Networking are missing. Moreover, current approaches which are mainly designed for internal use (e.g. Data Governance, information lifecycle management) should be transferred to network business scenarios. Apart from that, new research directions emerge as Business Networking is increasingly influenced by the "consumerization" of business and the further development of electronic markets. The relevance of information and data quality in Business Networking will grow with the proliferation of social networking and information products (e.g. business partner data), which in parallel leads to new fields of research.

\section{References}

Allemang, D. (2010). SemanticWeb and the linked data enterprise. In D. Wood (Ed.), Linking enterprise data (pp. 3-23). Berlin: Springer. doi:10.1007/978-1-4419-7665-9_1.

Alt, R., \& Fleisch, E. (2000). Business networking systems: characteristics and lessons learned. International Journal of Electronic Commerce, 5(2), 7-27.

Alt, R., \& Klein, S. (2011). Twenty years of electronic markets research-looking backwards towards the future. Electronic Markets, 21(1), 41-51. doi:10.1007/s12525-011-0057-Z

Alt, R., Fleisch, E., \& Werle, O. (2000). The concept of networkabilityhow to make companies competitive in business networks. Paper presented at the 8th European Conference on Information Systems (ECIS 2000), Vienna (Austria).

Alt, R., Fleisch, E., \& Österle, H. (2001). Introduction-chances and challenges in business networking. In H. Österle, E. Fleisch, \& R. Alt (Eds.), Business networking-shaping collaboration between enterprises (2nd ed., pp. 1-14). Berlin: Springer.

Applegate, L. M. (2001). Emerging Networked Business Models: Lessons from the Field, Working report No. 9-801-172, Harvard Business School.

Atkinson, K., \& McGaughey, R. (2006). Accounting for data: a shortcoming in accounting for intangible assets. Academy of Accounting and Financial Studies Journal, 10(2), 85-95.

Auramo, J., Kauremaa, J., \& Tanskanen, K. (2005). Benefits of IT in supply chain management: an explorative study of progressive companies. International Journal of Physical Distribution \& Logistics Management, 35(2), 82-100. doi:10.1108/09600030510590282.

Barnes, S. J., \& Vidgen, R. (2003). Measuring web site quality improvements: a case study of the forum on strategic management knowledge exchange. Industrial Management \& Data Systems, 103(5), 297-309. doi:10.1108/02635570310477352.

Batini, C., \& Scannapieco, M. (2006). Data quality. Concepts, methodologies and techniques. Berlin: Springer.

Batini, C., Cappiello, C., Francalanci, C., \& Maurino, A. (2009). Methodologies for data quality assessment and improvement. $A C M$ Computing Surveys, 41(3), 1-52. doi:10.1145/1541880.1541883.

Ben Hassine-Guetari, S. (2009). Data quality evaluation in an E-Business environment: A survey. Paper presented at the 14th International Conference on Information Quality, Potsdam (Germany).

Berti-Équille, L. (2007). Tracing data pollution in large business applications. Paper presented at the 13th International Conference on Information Quality, Cambridge, MA (USA). 
Caballero, I., Caro, A., Calero, C., \& Piattini, M. (2008). IQM3: information quality management maturity model. Journal of Universal Computer Science, 14(22), 3658-3685.

Cappiello, C., \& Pernici, B. (2008). Quality-aware design of repairable processes. Paper presented at the 13th International Conference on Information Quality, Cambridge, MA (USA).

Chung, W. Y., Fisher, C., \& Wang, R. (2002). What skillls matter in data quality? Paper presented at the 7th International Conference on Information Quality, Cambridge, MA (USA).

Claassen, M. J. T., van Weele, A. J., \& van Raaij, E. M. (2008). Performance outcomes and success factors of vendor managed inventory (VMI). Supply Chain Management: An International Journal, 13(6), 406-414. doi:10.1108/13598540810905660.

Cullen, A. J., \& Taylor, M. (2009). Critical success factors for B2B ecommerce use within the UK NHS pharmaceutical supply chain. International Journal of Operations \& Production Management, 29(11), 1156-1185. doi:10.1108/01443570911000177.

Davenport, T. H. (1998). Putting the enterprise into the enterprise system. Harvard Business Review, 76(4), 121-131.

Davenport, T. H., \& Short, J. E. (1990). The new industrial engineering: information technology and business process redesign. Sloan Management Review, 31(4), 11-27.

Dayal, U., Hsu, M., \& Ladin, R. (2001). Business process coordination: State of the art, trends, and open issues. Paper presented at the 27th VLDB Conference, Rome (Italy).

DeLone, W. H., \& McLean, E. R. (1992). Information systems success: the quest for the dependent variable. Information Systems Research, 3(1), 60-95. doi:10.1287/isre.3.1.60.

Dholakia, N., \& Firat, A. F. (2006). Global business beyond modernity. Critical Perspectives on International Business, 2(2), 147-162.

Diemers, D. (2000). A sociological framework for information quality in virtual knowledge communities. Paper presented at the 5th International Conference on Information Quality, Cambridge, MA (USA).

Dreibelbis, A., Hechler, E., Milman, I., Oberhofer, M., van Run, P., \& Wolfson, D. (2008). Enterprise master data management: an SOA approach to managing core information. Upper Saddle River: IBM.

English, L. P. (1999). Improving data warehouse and business information quality (1st ed.). New York, NY (USA): Wiley.

Eppler, M. J. (2001). A generic framework for information quality in knowledge-intensive processes. Paper presented at the 6th International Conference on Information Quality, Cambridge, MA (USA).

Eppler, M. J., \& Helfert, M. (2004). A framework for the classification of data quality costs and an analysis of their progression. Paper presented at the International Conference on Information Quality 2004, Cambridge, MA (USA).

Fairchild, A. (2006). Decision management: role and effect of using an intelligent intermediary to aid in information sharing. Information Technology and Management, 7(4), 249-258. doi:10.1007/s10799-006-0275-9.

Fedorowicz, J., Gogan, J. L., \& Culnan, M. J. (2010). Barriers to interorganizational information sharing in e-government: a stakeholder analysis. The Information Society: An International Journal, 26(5), 315-329. doi:10.1080/01972243.2010.511556.

FInES Cluster (2011). Position paper on orientations for FP8: A European innovation partnership for catalysing the competitiveness of European enterprises. European Commsion, Future Internet Enterprise Systems (FInES) Cluster, Brussels (Belgium).

Fleisch, E., \& Österle, H. (2000). Business networking: A processoriented framework. In H. Österle, E. Fleisch, \& R. Alt (Eds.), Business networking-shaping enterprise relationships on the internet (pp. 55-91). Berlin: Springer.

Forslund, H., \& Jonsson, P. (2007). The impact of forecast information quality on supply chain performance. International Journal of Operations \& Production Management, 27(1), 90-107. doi:10.1108/01443570710714556.
Global Commerce Initiative, Capgemini, SAP, HP (2008) 2018: The Future Value Chain

Gregor, S. (2006). The nature of theory in information systems. MIS Quarterly, 30(3), 611-642.

Guimaraes, T., Armstrong, C, \& Jones, B. (2006). Evolving a comprehensive measure for system quality. Paper presented at the 11th International Conference on Information Quality, Cambridge, MA (USA).

Helfert, M., \& Radon, R. (2000). An approach for information quality measurement in data warehousing. Paper presented at the 5th International Conference on Information Quality, Cambridge, MA (USA).

Horne, N. W. (1995). Information as an asset: the board agenda. Computer Audit Update 1995 (9):5-11.

Kagermann, H., Osterle, H., \& Jordan, J. M. (2010). IT-Driven business models: Global case studies in transformation. Hoboken, NJ (USA): Wiley.

Kathri, V., \& Brown, C. V. (2010). Designing data governance. Communications of the ACM, 53(1), 148-152. doi:10.1145/ 1629175.1629210.

Kitchenham, B., Mendes, E., \& Travassos, G. H. (2006). A systematic review of cross- vs. within-company cost estimation studies. Paper presented at the 10th International Conference on Evaluation and Assessment in Software Engineering, Staffordshire (UK).

Kodate, A., Hario, D., Kawagishi, H., Tanaka, Y., Baba, T., \& Seki, S., et al. (2005). Requirements of new emerging services in the ubiquitous networking society based on IQ analysis. Paper presented at the 10th International Conference on Information Quality, Cambridge, MA (USA).

Lee, Y. W. (2004). Crafting rules: context-reflective data quality problem solving. Journal of Management Information Systems, 20(3), 93-119

Lee, Y. W., Strong, D. M., Kahn, B. K., \& Wang, R. Y. (2002). AIMQ: a methodology for information quality assessment. Information Management, 40, 133-146.

Legner, C., \& Lebreton, B. (2007). Preface to the focus theme section: 'Business interoperability' business interoperability research: present achievements and upcoming challenges. Electronic Markets, 17(3), 176-186. doi:10.1080/10196780701503054.

Legner, C., \& Wende, K. (2006). Towards an Excellence Framework for Business Interoperability. Paper presented at the 19th Bled eConference, Bled (Slovenia).

Lin, H.-F. (2007). The role of online and offline features in sustaining virtual communities: an empirical study. Internet Research, 17 (2), 119-138. doi:10.1108/10662240710736997.

Lin, C.-T. (2010). Examining e-travel sites: an empirical study in Taiwan. Online Information Review, 34(2), 205-288. doi:10.1108/14684521011036954.

Liu, X., He, M., Gao, F., \& Xie, P. (2008). An empirical study of online shopping customer satisfaction in China: a holistic perspective. International Journal of Retail \& Distribution Management, 36 (11), 919-940. doi:10.1108/09590550810911683.

Loonam, M., \& O'Loghlin, D. (2008). Exploring e-service quality: a study of Irish online banking. Marketing Intelligence \& Planning, 26(7), 759-780. doi:10.1108/02634500810916708.

Loshin, D. (2001). Enterprise knowledge management: The data quality approach. San Diego, CA (USA): Morgan Kaufmann.

Maditinos, D. I., \& Theodoridis, K. (2010). Satisfaction determinants in the Greek online shopping context. Information Technology \& People, 23(4), 312-329. doi:10.1108/09593841011087789.

Madnick, S., Wang, R., Dravis, F., \& Chen, X. (2001). Improving the quality of corporate household data: Current practices and research directions. Paper presented at the 6th International Conference on Information Quality, Cambridge, MA (USA).

Madnick, S, Wang, R., Lee, Y. W., \& Zhu, H. (2009). Overview and Framework for Data and Information Quality Research. ACM 
Journal of Data and Information Quality, Vol. 1, No. 1, Article 2. doi: $10.1145 / 1515693.1516680$

Malone, T. W., \& Crowston, K. (1994). The interdisciplinary study of coordination. ACM Computing Surveys, 26(1), 87-119.

MGB. (2010). Kult-Ice-Tea der Migros jetzt auch im PET. In U. P. Naef (Ed.), Press Release. Zürich (SUI): Migros-Genossenschafts-Bund.

Melkas, H. (2004). Analyzing information quality in virtual service networks with qualitative interview data. Paper presented at the 9th International Conference on Information Quality, Cambridge, MA (USA).

Miles, R. E., \& Snow, C. C. (1992). Causes of failure in network organizations. California Management Review, 34(4), 53-72.

Moebius, M. (2002). Reasons for rejecting extranet technology in channel relationships: A study of white goods retailers in Germany. Paper presented at the 10th European Conference on Information Systems (ECIS 2002), Gdańsk (Poland), 2002-06-06.

Moore, J. F. (1996). The death of competition: Leadership \& strategy in the age of business ecosystems. New York: Harper.

Najjar, L., \& Bishu, R. (2005). Information quality in the banking industries. Paper presented at the 11th Americas Conference on Information Systems (AMCIS 2005), Omaha, NE (USA).

Nakatani, K., Chuang. T.-T., \& Zhou, D. (2006). Data synchronization technology: Standards, business values and implications. Communications of the AIS, 17(1):Art. 44.

Nath, T., \& Standing, C. (2010). Drivers of information technology use in the supply chain. Journal of Systems and Information Technology, 12(1), 70-84. doi:10.1108/13287261011032661.

Oliveira, P., Rodrigues, F., \& Henriques, P. (2006). An ontology-based approach for data cleansing. Paper presented at the 11th International Conference on Information Quality, Cambridge, MA (USA).

Österle, H. (1996). Business engineering: Transition to the networked enterprise. Electronic Markets, 6(2), 14-16.

Österle, H., \& Winter, R. (2003). Business engineering. In H. Österle \& R. Winter (Eds.), Business engineering (Vol. 2, pp. 3-18). Berlin (Germany): Springer.

Österle, H., Fleisch, E., \& Alt, R. (1999). Business networking. Shaping enterprise relationships on the internet. Berlin (Germany): Springer.

Osterwalder, A., \& Pigneur, Y. (2010). Business model generation: A handbook for visionaries, game changers, and challengers. Hoboken, NJ (USA): Wiley.

Otto, B. (2011). Quality management of corporate data assets. In C.-P. Praeg \& D. Spath (Eds.), Quality management for IT services: Perspectives on business and process performance (pp. 193209). Hershey, PA (USA): IGI Global.

Otto, B., \& Ofner, M. (2010). Towards a process reference model for information supply chain management. Paper presented at the 18th European Conference on Information Systems (ECIS 2010), Pretoria (South Africa).

Otto, B., \& Schmidt, A. (2010). Enterprise master data architecture: Design decisions and options. Paper presented at the Proceedings of the 15th International Conference on Information Quality, Little Rock, AR (USA).

Otto, B., Wende, K., Schmidt, A., \& Osl, P. (2007). Towards a framework for corporate data quality management. Paper presented at the 18th Australasian Conference on Information Systems, Toowoomba (Australia).

Park, C.-H., \& Kim, Y.-G. (2003). Identifying key factors affecting consumer purchase behavior in an online shopping context. International Journal of Retail \& Distribution Management, 31 (1), 16-29. doi:10.1108/09590550310457818.

Pokorny, L. R. (2006). Determining the cost and effectiveness of enhancing data in the U.S. Defense Logistics Agency supply chain. Paper presented at the 11th International Conference on Information Quality, Cambridge, MA (USA).
Redman, T. C. (1995). Improve data quality for competitive advantage. Sloan Management Review, 36(2), 99-107.

Redman, T. C. (2001). Data quality. The field guide. Boston: Digital Press.

Riemer, K., \& Klein, S. (2006). Network management framework. In S. Klein \& A. Poulymenakou (Eds.), Managing dynamic networks (pp. 17-66). Berlin (Germany): Springer.

Rotchanakitumnuai, S., \& Speece, M. (2009). Modeling electronic service acceptance of an e-securities trading system. Industrial Management \& Data Systems, 109(8), 1069-1084. doi:10.1108/ 02635570910991300.

Sarkis, J., \& Sundarraj, R. P. (2000). Quality and process standards for electronic commerce. Paper presented at the 5th International Conference on Information Quality, Cambridge, MA (USA).

Sarner, A., Drakos, N., \& Prentice, S. (2008). The Business Impact of Social Computing. Stamford, CT (USA): Gartner, Inc.

Sarsfield. (2009). The data governance imperative: A business strategy for corporate data. Cambridgeshire (UK): IT Governance Publishing.

Seethamraju, R. (2005). Relative importance of web quality dimensions. Paper presented at the 11th Americas Conference on Information Systems (AMCIS 2005), Omaha, NE (USA).

Shankaranarayan, G., Wang, R. Y., \& Ziad, M. (2000). IP-MAP: Representing the manufacture of an information product. Paper presented at the 2000 Conference on Information Quality, Cambridge, MA (USA).

Shankaranarayanan, G., \& Cai, Y. (2006). Supporting data quality management in decision-making. Decision Support Systems, 42 (1), 302-317. doi:10.1016/j.dss.2004.12.006.

Shannon, C. E. (1949). Communication in the presence of noise. Proceedings of the IRE, 37, 10-21.

Stvilia, B., Gasser, L., Twidale, M. B., Shreeves, S. L., \& Cole, T. W. (2004). Metadata quality for federated collections. Paper presented at the 9th International Conference on Information Quality, Cambridge, MA (USA).

Su, Q., Li, Z., Y-T, S., \& Chen, T. (2008). Conceptualizing consumers' perceptions of e-commerce quality. International Journal of Retail \& Distribution Management, 36(5), 360-374. doi:10.1108/09590550810870094.

Swaid, S. I., \& Wigand, R. T. (2007). Key dimensions of e-commerce service quality and its relationships to satisfaction and loyalty. Paper presented at the Bled eConference 2007, Bled (Slovenia),

Tapia, R. S. (2006). What is a networked business? University of Twente, Department of Computer Science, Enschede (The Netherlands).

Timmers, P. (1999). Business models for electronic markets. Electronic Markets, 8(2), 3-8.

Van den Hoven, J. (1999). Information resource management: stewards of data. Information Systems Management, 16(1), 88-91.

Wang, R. Y. (1998). A product perspective on total data quality management. Communications of the ACM, 41(2), 58-65.

Wang, R. Y., \& Strong, D. (1996). Beyond accuracy: what data quality means to data consumers. Journal of Management Information Systems, 12(4), 5-34.

Wang, R. Y., Storey, V. C., \& Firth, C. P. (1995). A framework for analysis of data quality research. IEEE Transactions on Knowledge and Data Engineering, 7(4), 623-640.

Wang, R. Y., Lee, Y. W., Pipino, L. L., \& Strong, D. M. (1998). Manage your information as a product. Sloan Management Review, 39(4), 95-105.

Webb, H. W., \& Webb, L. A. (2004). SiteQual: an integrated measure of Web site quality. The Journal of Enterprise Information Management, 17(6), 430-440. doi:10.1108/17410390410566724.

Weber, K., Otto, B., \& Österle, H. (2009). One Size Does Not Fit All A Contingency Approach to Data Governance. ACM Journal of Data and Information Quality, Vol. 1, No. 1, Article 4. doi:10.1145/1515693.1515696. 
Wigand, R. T., Wood, J., \& Yiliyasi, Y. (2009). Information quality issues in the mortgage banking industry. Paper presented at the 14th International Conference on Information Quality, Potsdam (Germany)

Williamson, O. E. (1979). Transaction-cost economics: the governance of contractual relations. Journal of Law and Economics, 22 (2), 233-261.

Wilson, R. M. S., \& Stenson, J. A. (2008). Valuation of information assets on the balance sheet: the recognition and approaches to the valuation of intangible assets. Business Information Review, 25 (3), 167-182.

Winter, R. (2008). Design science research in Europe. European Journal of Information Systems, 17(5), 470-475. doi:10.1057/ ejis.2008.44.
Yao, Y., \& Murphy, L. (2007). Remote electronic voting systems: an exploration of voters' perception and intention to use. European Journal of Information Systems, 16(2), 106-120. doi:10.1057/ palgrave.ejis.3000672.

Zhou, T., Li, H., \& Liu, Y. (2010). The effect of flow experience on mobile SNS users' loyalty. Industrial Management \& Data Systems, 110(6), 930-946. doi:10.1108/02635571011055126.

Zhu, H., \& Fu, L. (2009a). Towards quality of data standards: Empirical findings from XBRL. Paper presented at the International Conference on Information Systems (ICIS 2009), Phoenix, AZ (USA).

Zhu, H., \& Wu, H. (2009b). Sloppy Tags and Metacrap? Quality of User Contributed Tags in Collaborative Social Tagging Systems. Paper presented at the 15th Americas Conference on Information Systems (AMCIS 2009), San Francisco, CA (USA). 